INOBIS: Jurnal Inovasi Bisnis dan Manajemen Indonesia

Volume 1, Nomor 2, Maret 2018

Nyoman Gede Aditya Jay Medhika; I Gusti Ayu Ketut Giantri; Ni Nyoman Kerti Yasa

\title{
Peran Keuanggulan Bersaing dalam Memediasi Orientasi Pasar dan Orientasi Kewirausahaan dengan Kinerja UKM
}

\author{
Nyoman Gede Aditya Jay Medhika ${ }^{1}$ \\ I Gusti Ayu Ketut Giantari ${ }^{2}$ \\ Ni Nyoman Kerti Yasa ${ }^{3}$ \\ ${ }^{12}$ Fakultas Ekonomi dan Bisnis Universitas Udayana (Unud), Bali, Indonesia \\ e-mail: ayugiantari@unud.ac.id
}

\begin{abstract}
Abstrak
Penelitian ini bertujuan untuk menjelaskan: 1) pengaruh orientasi pasar dan orientasi kewirausahaan terhadap keunggulan bersaing UKM, 2) pengaruh orientasi pasar, orientasi kewirausahaan dan keunggulan bersaing terhadap kinerja UKM dan 3) peran keunggulan bersaing dalam memediasi pengaruh orientasi pasar dan orientasi kewirausahaan terhadap kinerja UKM industri kerajinan 'kain endek' (kain tenun ikat) di Kabupaten Klungkung. Populasi dalam penelitian ini adalah UKM di industri kerajinan kain endek di Kabupaten Klungkung yang terdaftar di Dinas Perindustrian dan Perdagangan Provinsi Bali tahun 2016. Penelitian ini menggunakan sampel jenuh (sensus), dimana menggunakan keseluruhan populasi yaitu 37 usaha sebagai unit analisis. Data dianalisis menggunakan teknik analisis SEM berbasis PLS (Partial Least Square). Hasil penelitian menunjukkan bahwa orientasi pasar dan orientasi kewirausahaan berpengaruh positif dan signfikan terhadap keunggulan bersaing UKM. Orientasi pasar, orientasi kewirausahaan dan keunggulan bersaing berpengaruh positif dan signfikan terhadap kinerja UKM. Keunggulan bersaing secara positif dan signifikan memediasi pengaruh orientasi pasar dan orientasi kewirausahaan terhadap kinerja UKM industri kerajinan endek di Kabupaten Klungkung.
\end{abstract}

Kata kunci: Orientasi Pasar, Orientasi Kewirausahaan, Keunggulan Bersaing, Kinerja UKM

\section{Pendahuluan}

Persaingan di dunia usaha semakin lama semakin meningkat, salah satu langkah strategis dalam rangka mengatasi masalah ketimpangan ekonomi dan kesenjangan sosial yang dapat dilakukan adalah dengan mengembangkan Usaha Kecil dan Menengah (UKM), karena UKM menggunakan teknologi sederhana dan menyerap tenaga kerja sehingga dapat mewujudkan pemerataan kesempatan berusaha dan pemerataan pendapatan yang nantinya akan membantu meningkatkan perekonomian dan pendapatan daerah (Usvita, 2014). Negara-negara berkembang telah mengubah orientasinya dengan memberdayakan sektor UKM ketika melihat pengalaman di negara-negara industri maju tentang pentingnya peranan sektor UKM dan sumbangannya dalam mendukung memperkokoh pertumbuhan perekonomian rakyat dalam rangka mewujudkan dan mempertahankan daya saing nasional dan bahkan di tingkat global (Lumbanraja, 2011). Hadiyati (2011) menyatakan, meningkatnya jumlah UKM dapat ditinjau dari berbagai aspek meliputi; jumlah industrinya yang besar dan terdapat dalam setiap sektor, memiliki potensi dalam menciptakan lebih banyak lapangan kerja dibandingkan investasi yang sama pada usaha skala 
INOBIS: Jurnal Inovasi Bisnis dan Manajemen Indonesia

Volume 1, Nomor 2, Maret 2018

Nyoman Gede Aditya Jay Medhika; I Gusti Ayu Ketut Giantri; Ni Nyoman Kerti Yasa

yang lebih besar, kontribusi UKM dalam pembentukan PDB cukup signifikan, memberikan sumbangan devisa kepada Negara dengan nilai ekspor yang cukup stabil. Semakin meningkatnya jumlah UKM di Indonesia maka semakin kompetitif persaingan antar usaha. Setiap usaha dituntut untuk mampu menonjolkan keunggulan bersaingnya dari produk atau jasa yang dihasilkannya yang kemudian memindai kinerja perusahaanya untuk tetap dapat bertahan dan bersaing di pasar (Pramesti dan Giantari, 2016).

Pada persaingan usaha yang ketat, usaha kecil dituntut untuk mampu melakukan proses manajemen usaha yang produktif dan seefisien mungkin, serta dapat menghasilkan produk atau jasa yang sesuai dengan preferensi pasar dengan standar kualitas yang lebih baik dibandingkan dengan pesaing, sehingga mampu meningkatkan kinerja usahanya (Alimudin, 2014). Hasan (2014: 277) menyatakan bahwa keunggulan bersaing yang mampu bertahan merupakan kunci superiornya kinerja bisnis jangka panjang. Untuk mendapatkan kinerja yang secara konsisten di atas normal, perusahaan harus memiliki suatu keunggulan bersaing. Narver dan Slater (1990) menyatakan bahwa keunggulan bersaing dapat dicapai apabila perusahaan mampu memberikan nilai yang lebih kepada pelanggan dari apa yang diberikan oleh pesaingnya. Pendapat yang serupa juga dikemukakan oleh Porter (1990: 3) yang menjelaskan bahwa keunggulan bersaing adalah jantung kinerja perusahaan untuk menghadapi persaingan. Menurut Usvita (2014) dalam penilitiannya, kinerja UKM dan keunggulan bersaing dapat dipengaruhi oleh dua strategi orientasi, yaitu orientasi pasar dan orientasi kewirausahaan. Menurut Kotler dan Amstrong (2012: 39) kinerja usaha sangat dipengaruhi oleh kemampuan perusahaan dalam menciptakan nilai bagi pelanggannya. Dalam hal ini, budaya berorientasi pada pasar diperlukan untuk membangun dan mempertahankan kemampuan inti untuk terus menciptakan nilai pelanggan yang superior (Halim dkk, 2011). Narver dan Slater (1990) mendefinisikan orientasi pasar sebagai budaya organisasi yang paling efektif dan efisien untuk menciptakan perilaku-perilaku yang dibutuhkan untuk menciptakan superior value bagi pembeli dan menghasilkan superior performance bagi perusahaan, apalagi dalam lingkungan yang bersaing ketat. Lumpkin \& Dess (1996) mendefinisikan orientasi kewirausahaan sebagai proses, praktek dan aktifitas pembuat keputusan (orientasi kewirausahaan) yang mendorong new entry (kewirausahaan), yang dimana perusahaan dengan orientasi kewirausahaan akan menjadi lebih inovatif, perusahaan akan memiliki kemampuan dan bersedia untuk mendukung kreatifitas, ide-ide baru, dan eksperimen yang menghasilkan produk atau jasa baru.

Tabel 1. Jumlah UKM Industri Kerajinan Kain Endek di masing-masing Kabupaten/ Kota di Provinsi Bali Tahun 2016

\begin{tabular}{lc}
\hline \multicolumn{1}{c}{ Kabupaten/ Kota } & Jumlah UKM \\
\hline Kabupaten Jembrana & 27 \\
Kabupaten Tabanan & 1 \\
Kabupaten Badung & 2 \\
Kota Denpasar & 4 \\
Kabupaten Buleleng & 5 \\
Kabupaten Gianyar & 9 \\
Kabupaten Klungkung & 63 \\
Kabupaten Bangli & 0 \\
Kabupaten Karangasem $\quad 20$ \\
\hline \multicolumn{2}{c}{ Jumlah } \\
\multicolumn{2}{c}{ Sumber: Dinas Perindustrian dan Perdagangan Provinsi Bali Tahun 2016 }
\end{tabular}


INOBIS: Jurnal Inovasi Bisnis dan Manajemen Indonesia

Volume 1, Nomor 2, Maret 2018

Nyoman Gede Aditya Jay Medhika; I Gusti Ayu Ketut Giantri; Ni Nyoman Kerti Yasa

Penelitian ini berfokus pada usaha kerajinan kain endek di Kabupaten Klungkung karena Kabupaten Klungkung merupakan sentra kain endek di Provinsi Bali dan telah mulai dikenal, baik oleh masyarakat lokal maupun mancanegara (Pramesti dan Giantari, 2016). Berdasarkan data yang diperoleh dari Dinas Perindustrian dan Perdagangan Provinsi Bali pada tahun 2016 terdapat 135 unit UKM industri kerajinan kain endek yang berkembang di tiap kabupaten. Hampir semua proses produksi dilakukan secara manual dan memerlukan waktu yang relatif lama sehingga 'kain endek' merupakan kerajinan tangan yang memiliki keunikan berbasis budaya lokal. Meskipun demikian, potensi yang dimiliki oleh industri kain endek tidak diimbangi dengan kemampuan untuk bersaing. Menurut Dewi dan Suparna (2017) dewasa ini industri 'kain endek' di Kabupaten Klungkung mengalami persaingan ketat yang dikarenakan munculnya pesaing baik itu dari Provinsi Bali sendiri maupun dari luar Provinsi Bali. Munculnya beberapa pesaing usaha tersebut yang mampu memproduksi kain endek dengan harga jauh lebih murah dengan menggunakan alat tenun mesin namun memiliki standar kualitas yang lebih rendah. Jika hal ini berlangsung terus-menerus maka industri 'kain endek' tradisional di Kabupaten Klungkung akan tergeser.

Tujuan penelitian ini adalah untuk menjelaskan pengaruh orientasi pasar dan orientasi kewirausahaan terhadap keunggulan bersaing UKM, untuk menjelaskan pengaruh orientasi pasar, orientasi kewirausahaan dan keunggulan bersaing terhadap kinerja UKM, serta menjelaskan peran keunggulan bersaing dalam memediasi pengaruh orientasi pasar dan orientasi kewirausahaan terhadap kinerja UKM industri kerajinan kain endek di Kabupaten Klungkung.

\section{Landasan Teori dan Hipotesis Penelitian}

Orientasi pasar pada usaha kecil merupakan respon terus menerus kepada keinginan dan kebutuhan dari pelanggan sehingga hal ini dapat memfasilitasi pengembangan strategi yang difokuskan pada penciptaan nilai pelanggan, untuk mencapai keunggulan bersaing (Didonet et al., 2012). Penelitian yang dilakukan Akhiri (2016) menemukan bahwa orientasi pasar berpengaruh positif dan signifikan terhadap keunggulan bersaing pada UKM pengolahan Tepung Tapioka Di Ngemplak Kidul Margoyoso Kabupaten Pati. Penelitian yang dilakukan Usvita (2014), Helia dkk (2015), membuktikan bahwa orientasi pasar memiliki pengaruh positif dan signifikan terhadap keunggulan bersaing. Berdasarkan penelitian diatas, dapat dikemukakan hipotesis sebagai berikut :

\section{H1 : Orientasi pasar berpengaruh positif dan signfikan terhadap keunggulan bersaing}

Halim, dkk. (2011) mendefinisikan orientasi kewirausahaan sebagai entrepreneurial perusahaan yang berkaitan dengan inovasi produk, melakukan kegiatan yang beresiko dan yang pertama memperkenalkan inovasi yang proaktif serta dalam persaingan yang agresif maka diperlukan kegiatan yang intensif untuk mengungguli pesaing yang dicirikan dengan mengkombinasikan postur atau respon agresif untuk meningkatkan posisi dalam persaingan. Penelitian yang dilakukan Usvita (2014) menemukan bahwa orientasi kewirausahaan berpengaruh positif dan signifikan terhadap keunggulan bersaing pada UKM Pangan Dinas Perindagtamben Kota Padang. Penelitian tersebut menjelaskan bahwa semakin UKM tersebut berorientasi kewirausahaan, maka akan semakin besar peluang untuk menciptakan sebuah keunggulan bersaing. Penelitian yang dilakukan Akhiri (2016) dan Hajar dan Sukaatmadja (2016) 
INOBIS: Jurnal Inovasi Bisnis dan Manajemen Indonesia

Volume 1, Nomor 2, Maret 2018

Nyoman Gede Aditya Jay Medhika; I Gusti Ayu Ketut Giantri; Ni Nyoman Kerti Yasa

menemukan bahwa kewirausahaan berpengaruh positif dan signifikan terhadap keunggulan bersaing. Berdasarkan penelitian diatas, dapat dikemukakan hipotesis sebagai berikut :

\section{H2 : Orientasi kewirausahaan berpengaruh positif dan signfikan terhadap keunggulan bersaing}

Hartini (2017) menyatakan bahwa peningkatan kinerja menjadi kunci keberhasilan setiap perusahaan, termasuk UKM, perusahaan dengan budaya orientasi pasar yang tinggi fokus pada perannya dalam kontribusi untuk menciptakan nilai pelanggan yang superior, peningkatan pengelolaan produk termasuk penciptaan produk yang berkualitas, dan ini akan mengarahkan pada posisi persaingan superior yang pada akhirnya berdampak pada kinerja perusahaan. Penelitian yang dilakukan Pramesti dan Giantari (2016) dan Setiawan (2013) menemukan bahwa variabel orientasi pasar berpengaruh positif dan signifikan terhadap Kinerja Usaha Kecil. Berdasarkan penelitian diatas, dapat dikemukakan hipotesis sebagai berikut :

\section{H3: Orientasi pasar berpengaruh positif dan signfikan terhadap kinerja}

Menurut Setiawan (2013), orientasi kewirausahaan sebagai pendekatan baru dalam pembaruan kinerja perusahaan oleh perusahaan yang mulai mencoba bangkit dari keterpurukan ekonomi akibat krisis yang berkepanjangan, bentuk dari aplikasi atas sikap-sikap orientasi kewirausahaan dapat diindikasikan dengan indikasi kemampuan inovasi, proaktif, dan kemampuan mengambil risiko. Penelitian yang dilakukan Pramesti dan Giantari (2016) menemukan bahwa orientasi kewirausahaan berpengaruh positif dan signifikan terhadap kinerja pada UKM endek di Kabupaten Klungkung. Hasil penelitian ini memiliki arti bahwa meningkatnya budaya orientasi kewirausahaan pada UKM endek di Kabupaten Klungkung akan mampu meningkatkan kinerja UKM. Penelitian yang dilakukan Setiawan (2013) dan Hajar dan Sukaatmadja (2016) menemukan bahwa variabel orientasi kewirausahaan berpengaruh positif dan signifikan terhadap Kinerja Usaha Kecil. Berdasarkan penelitian diatas, dapat dikemukakan hipotesis sebagai berikut :

\section{H4 : Orientasi kewirausahaan berpengaruh positif dan signfikan terhadap kinerja}

Assauri (2012:19) berpendapat bahwa, orientasi pasar merupakan suatu perspektif bisnis yang membuat pelanggan sebagai titik pusat pandangan atas operasi perusahaan secara menyeluruh: Pada dasarnya perusahaan haruslah berorientasi pada pasar, sehingga dibutuhkannya budaya yang secara sistematik dan menyeluruh untuk berkomitmen secara berkelanjutan bagi penciptaan sebuah keunggulan bersaing, dan pencapaian orientasi pasar haruslah dapat mencakup penggunaan keterampilan atau skills pengorganisasian yang superior, terutama dalam memahami dan memuaskan pelanggan, dimana untuk dapat memenuhi rumusan orientasi pasar, dibutuhkan upaya untuk mengumpukan informasi tentang pelanggan, para pesaing dan pasar, dan dengan orientasi pasar, suatu perusahaan haruslah mampu secara berkelanjutan memantau perubahan kebutuhan dan keinginan pelanggan dengan cepat dan tepat. Fatonah (2009) dalam penelitiannya menemukan bahwa, orientasi pasar berpengaruh signifikan terhadap kinerja pemasaran langsung maupun tidak langsung melalui keunggulan bersaing perusahaan Batik. Penelitian yang dilakukan Usvita (2014) juga menyatakan bahwa keunggulan bersaing mampu memediasi 
INOBIS: Jurnal Inovasi Bisnis dan Manajemen Indonesia

Volume 1, Nomor 2, Maret 2018

Nyoman Gede Aditya Jay Medhika; I Gusti Ayu Ketut Giantri; Ni Nyoman Kerti Yasa

hubungan orientasi pasar dan kinerja UKM. Berdasarkan penelitian di atas, dapat dikemukakan Hipotesis sebagai berikut :

\section{H5: Keunggulan bersaing secara positif dan signifikan memediasi pengaruh orientasi pasar terhadap kinerja}

Gradistya dan Farida (2016) menyatakan bahwa, orientasi kewirausahaan akan meningkatkan cara berfikir dan bertindak secara proaktif, dimana kemampuan pemilik UMKM akan sangat mempengaruhi keberlangsungan usaha, dan pemilik akan cenderung memperhatikan perubahan pasar, kebutuhan pasar, serta kemungkinan perancangan produk baru melalui inovasi untuk mengimbangi perubahan keinginan dan kebutuhan konsumen sehingga dapat meningkatkan kinerja usahanya. Mahmood dan Hanafi (2013) dalam penelitiannya menemukan bahwa, efek mediasi parsial keunggulan bersaing juga ditemukan pada hubungan antara orientasi kewirausahaan dan kinerja bisnis. Penelitian yang dilakukan Alimudin (2014), Usvita (2014) dan Hajar dan Sukaatmadja (2016) menemukan bahwa keunggulan bersaing memediasi pengaruh orientasi kewirausahaan terhadap kinerja. Berdasarkan penelitian di atas, dapat dikemukakan Hipotesis sebagai berikut :

\section{H6: Keunggulan bersaing secara positif dan signifikan memediasi pengaruh orientasi kewirausahaan terhadap kinerja}

Ekawati et al. (2016) menyatakan bahwa dengan memiliki keunggulan bersaing maka perusahaan akan mampu bertahan untuk melanjutkan hidup perusahaan. Keunggulan bersaing mutlak harus dimiliki oleh perusahaan/produk untuk mencapai kinerja atau sukses produk yang dihasilkan. Hasil penelitian ini memiliki arti bahwa keunggulan bersaing adalah posisi keunggulan UKM di pasar melalui kompetensi khas dan aset strategis perusahaan. Penelitian yang dilakukan oleh Hajar dan Sukaatmadja (2016) menemukan bahwa keunggulan bersaing berpengaruh positif dan signifikan terhadap kinerja. Berdasarkan penelitian diatas, dapat dikemukakan hipotesis sebagai berikut :

\section{H7: Keunggulan bersaing berpengaruh positif signfikan terhadap kinerja}

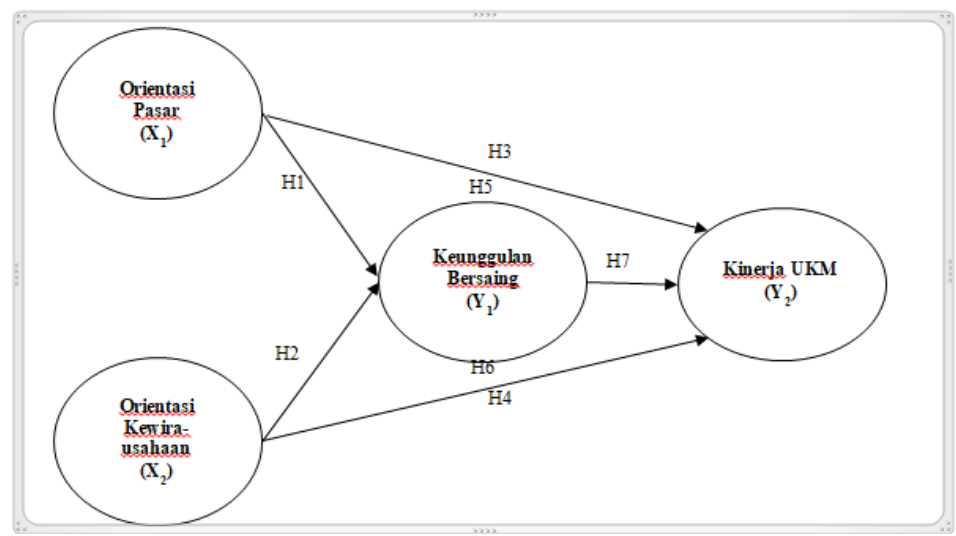

Gambar 1. Kerangka Model Penelitian 
INOBIS: Jurnal Inovasi Bisnis dan Manajemen Indonesia

Volume 1, Nomor 2, Maret 2018

Nyoman Gede Aditya Jay Medhika; I Gusti Ayu Ketut Giantri; Ni Nyoman Kerti Yasa

\section{Metode Penelitian}

Jenis penelitian ini digolongkan ke dalam penelitian asosiatif yaitu, penelitian yang bertujuan untuk mengetahui hubungan antara dua variabel atau lebih. Penelitian ini dilakukan pada industri kerajinan kain endek di Kabupaten Klungkung. Populasi dalam penelitian ini adalah UKM di industri kerajinan kain endek di Kabupaten Klungkung yang terdaftar di Dinas Perindustrian dan Perdagangan Provinsi Bali tahun 2016. Berdasarkan data yang diperoleh dari Dinas Perindustrian dan Perdagangan Provinsi Bali tahun 2016 mengenai jumlah usaha endek, Kabupaten Klungkung memiliki 63 unit usaha yang terdaftar di tahun 2016. Setelah dilakukannya survei lapangan, Kabupaten Klungkung memiliki 37 unit usaha kerajinan endek sedangkan sisanya 26 usaha telah mengalihkan usahanya pada industri lain. Penelitian ini menggunakan sampel jenuh (sensus), dimana menggunakan keseluruhan populasi yaitu 37 usaha sebagai unit analisis. Setiap indikator penelitian diukur dengan menggunakan skala likert 1-5 poin skala dan drajat persetujuan dari sangat setuju sampai sangat tidak setuju Alat analisis yang digunakan dalam penelitian ini adalah SEM berbasis PLS (Partial Least Square).

Tabel 2.Kisi - kisi Instrumen Penelitian

\begin{tabular}{|c|c|c|}
\hline Variabel & Indikator & Sumber \\
\hline \multirow{4}{*}{$\begin{array}{l}\text { Orientasi Pasar } \\
\left(\mathrm{X}_{1}\right)\end{array}$} & 1. Orientasi Pelanggan $\left(\mathrm{X}_{1.1}\right)$ & Zhang dan Bruning \\
\hline & 2. Orientasi Pesaing $\left(\mathrm{X}_{1.2}\right)$ & (2011), Narver dan \\
\hline & 3. Informasi Pasar $\left(\mathrm{X}_{1.3}\right)$ & Slater (1990) dan \\
\hline & $\begin{array}{l}\text { 4. Koordinasi Antarfungsi } \\
\left(\mathrm{X}_{1.4}\right)\end{array}$ & $\begin{array}{l}\text { Pramesti dan Giantari } \\
\text { (2016) }\end{array}$ \\
\hline \multirow{4}{*}{$\begin{array}{l}\text { Orientasi } \\
\text { Kewirausahaan } \\
\left(\mathrm{X}_{2}\right)\end{array}$} & 1. Inovasi $\left(\mathrm{X}_{2.1}\right)$ & Lumpkin dan Dess \\
\hline & 2. Proaktif $\left(\mathrm{X}_{2.2}\right)$ & (1996), Mahmood dan \\
\hline & 3. Pengambilan Risiko $\left(\mathrm{X}_{2.3}\right)$ & Hanafi (2013), Hajar \\
\hline & 4. Keagresifan Bersaing $\left(\mathrm{X}_{2.4}\right)$ & $\begin{array}{l}\text { (2016) dan Pramesti dan } \\
\text { Giantari (2016) }\end{array}$ \\
\hline \multirow{4}{*}{$\begin{array}{l}\text { Keunggulan } \\
\text { Bersaing }\left(\mathrm{Y}_{1}\right)\end{array}$} & 1. Keunikan Produk $\left(\mathrm{Y}_{1.1}\right)$ & Song dan Parry (1997), \\
\hline & 2. Kualitas Produk $\left(\mathrm{Y}_{1.2}\right)$ & Mahmood dan Hanafi \\
\hline & 3. Harga Bersaing $\left(\mathrm{Y}_{1.3}\right)$ & (2013), dan Hajar dan \\
\hline & 4. Tidak Mudah Ditiru $\left(\mathrm{Y}_{1.4}\right)$ & Sukaatmadja (2016) \\
\hline \multirow[t]{5}{*}{ Kinerja UKM $\left(\mathrm{Y}_{2}\right)$} & $\begin{array}{l}\text { 1. Pertumbuhan Penjualan } \\
\left(\mathrm{Y}_{2.1}\right)\end{array}$ & $\begin{array}{l}\text { Shahbaz et al. (2014), } \\
\text { Zhang dan Bruning }\end{array}$ \\
\hline & 2. Profitabilitas $\left(\mathrm{Y}_{2.2}\right)$ & (2011), Mahmood dan \\
\hline & 3. Produktifitas $\left(\mathrm{Y}_{2.3}\right)$ & Hanafi (2013), Hajar dan \\
\hline & 4. Peningkatan Jumlah & Sukaatmadja (2016), dan \\
\hline & Pelanggan $\left(\mathrm{Y}_{2.4}\right)$ & $\begin{array}{l}\text { Pramesti dan Giantari } \\
\text { (2016) }\end{array}$ \\
\hline
\end{tabular}

Sumber: Zhang dan Bruning (2011), Narver dan Slater (1990), Pramesti dan Giantari (2016), Lumpkin dan Dess (1996), Mahmood dan Hanadfi (2013), Hajar dan Sukaatmadja (2016), Song dan Parry (1997), dan Shahbaz et al. (2014). 
INOBIS: Jurnal Inovasi Bisnis dan Manajemen Indonesia

Volume 1, Nomor 2, Maret 2018

Nyoman Gede Aditya Jay Medhika; I Gusti Ayu Ketut Giantri; Ni Nyoman Kerti Yasa

\section{Hasil dan Pembahasan Penelitian}

\subsection{Uji Outer Model}

\section{1) Uji Validitas}

a. Convergent validity dengan indikator refleksif dapat dilihat dari korelasi antara skor indikator dengan skor variabelnya. Indikator individu dianggap reliabel apabila memiliki nilai korelasi diatas 0,50 . Hasil pengujian convergent validity mendapatkan hasil bahwa seluruh nilai outer loading indikator variabel memiliki nilai lebih besar dari 0,50. Dengan demikian, dapat disimpulkan bahwa seluruh indikator telah memenuhi persyaratan convergent validity.

b. Discriminant validity, pengujian discriminant validity lainnya adalah dengan cara menilai validitas dari variabel dari nilai average variance extracted (AVE). Model dikatakan baik jika AVE masing-masing variabel nilainya lebih besar dari 0,50. Hasil output pada pada penelitian ini menunjukkan bahwa nilai AVE seluruh variabel lebih besar dari 0,50 sehingga model dapat dikatakan baik.

\section{2) Uji Reliabilitas}

Disamping uji validitas, juga dilakukan uji reliabilitas variabel yang diukur dengan dua kriteria yaitu composite reliability dan cronbachs alpha dari blok indikator yang mengukur variabel. Variabel dinyatakan reliabel jika nilai composite reliability maupun cronbachs alpha diatas 0,70. Hasil output composite reliability dan cronbachs alpha variabel orientasi pasar, orientasi kewirausahaan, keunggulan bersaing, dan kinerja UKM semuanya diatas 0,70. Dengan demikian, dapat dijelaskan bahwa seluruh variabel memiliki reliabilitas yang baik.

\subsection{Hasil Penelitian}

Penelitian ini menggunakan pendekatan analisis Partial Least Square (PLS) untuk melakukan uji terhadap hipotesis penelitian yang telah dikemukakan sebelumnya. Hasil analisis model empiris penelitian dengan menggunakan analisis Partial Least Square (PLS) ini dapat dilihat dalam Gambar 1 berikut:

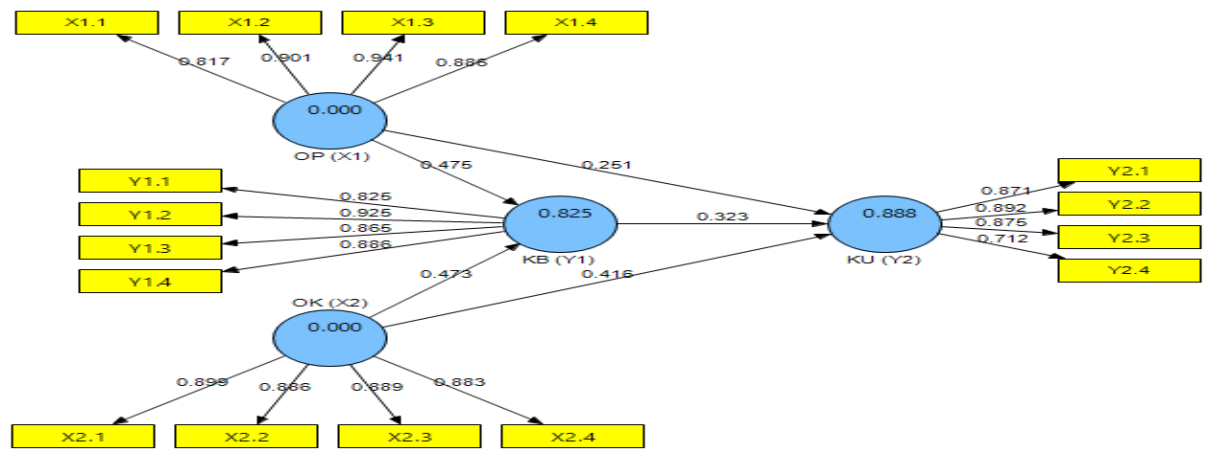

Gambar 2. Model Empiris Penelitian 
INOBIS: Jurnal Inovasi Bisnis dan Manajemen Indonesia

Volume 1, Nomor 2, Maret 2018

Nyoman Gede Aditya Jay Medhika; I Gusti Ayu Ketut Giantri; Ni Nyoman Kerti Yasa

Pada Tabel 3 berikut, dijelaskan bahwa orientasi pasar berpengaruh langsung terhadap kinerja UKM dengan koefisien sebesar 0,251, orientasi kewirausahaan berpengaruh langsung terhadap kinerja UKM dengan koefisien sebesar 0,416. Orientasi pasar berpengaruh langsung terhadap keunggulan bersaing dengan koefisien sebesar 0,475. Orientasi kewirausahaan berpengaruh langsung terhadap keunggulan bersaing dengan koefisien sebesar 0,473. Keunggulan bersaing berpengaruh langsung terhadap kinerja UKM dengan koefisien sebesar 0,323 .

Tabel 3. Path Coefficients

\begin{tabular}{lccc}
\hline \multicolumn{1}{c}{ Koefisien Path Antar Variabel } & $\begin{array}{c}\text { Koefisien } \\
\text { Jalur }\end{array}$ & $\begin{array}{c}\boldsymbol{t} \\
\text { Statistics }\end{array}$ & Keterangan \\
\hline $\begin{array}{l}\text { Orientasi Pasar }\left(\mathrm{X}_{1}\right) \rightarrow \text { Kinerja } \\
\text { UKM }\left(\mathrm{Y}_{2}\right)\end{array}$ & 0,251 & 2,458 & Signifikan \\
$\begin{array}{l}\text { Orientasi Kewirausahaan }\left(\mathrm{X}_{2}\right) \rightarrow \\
\text { Kinerja UKM }\left(\mathrm{Y}_{2}\right)\end{array}$ & 0,416 & 4,151 & Signifikan \\
$\begin{array}{l}\text { Orientasi Pasar }\left(\mathrm{X}_{1}\right) \rightarrow \text { Keunggulan } \\
\text { Bersaing }\left(\mathrm{Y}_{1}\right)\end{array}$ & 0,475 & 9,911 & Signifikan \\
$\begin{array}{l}\text { Orientasi Kewirausahaan }\left(\mathrm{X}_{2}\right) \rightarrow \\
\text { Keunggulan Bersaing }\left(\mathrm{Y}_{1}\right)\end{array}$ & 0,473 & 10,226 & Signifikan \\
$\begin{array}{l}\text { Keunggulan Bersaing }\left(\mathrm{Y}_{1}\right) \rightarrow \\
\text { Kinerja UKM }\left(\mathrm{Y}_{2}\right)\end{array}$ & 0,323 & 2,121 & Signifikan \\
\hline
\end{tabular}

Sumber: Hasil olahan data, 2017

Tabel 3 menunjukkan bahwa pengujian hipotesis pada pengaruh orientasi pasar terhadap kinerja UKM menghasilkan nilai koefisien korelasi sebesar 0,251. Nilai $t$ Statistics didapat sebesar 2,458 (> t-kritis 1,96), maka pengaruh orientasi pasar terhadap kinerja UKM adalah signifikan. Dengan demikian, maka hipotesis $1\left(\mathrm{H}_{1}\right)$ yang menyatakan bahwa orientasi pasar berpengaruh positif dan signifikan terhadap kinerja UKM diterima.

Pengujian hipotesis pada pengaruh orientasi kewirausahaan terhadap kinerja UKM menghasilkan nilai koefisien korelasi sebesar 0,416. Nilai $t$ Statistics didapat 4,151 (> t-kritis 1,96), maka pengaruh orientasi kewirausahaan terhadap kinerja UKM adalah signifikan. Dengan demikian, maka hipotesis $2\left(\mathrm{H}_{2}\right)$ yang menyatakan bahwa orientasi kewirausahaan berpengaruh positif dan signifikan terhadap kinerja UKM diterima.

Pengujian hipotesis pada pengaruh orientasi pasar terhadap keunggulan bersaing menghasilkan nilai koefisien korelasi sebesar 0,475. Nilai $t$ Statistics didapat sebesar 9,911 (> tkritis 1,96), maka pengaruh orientasi pasar terhadap keunggulan bersaing adalah signifikan. Dengan demikian, maka hipotesis $3\left(\mathrm{H}_{3}\right)$ yang menyatakan bahwa orientasi pasar berpengaruh positif dan signifikan terhadap keunggulan bersaing diterima.

Pengujian hipotesis pada pengaruh orientasi kewirausahaan terhadap keunggulan bersaing menghasilkan nilai koefisien korelasi sebesar 0,473. Nilai $t$ Statistics didapat sebesar 10,226 (> tkritis 1,96), maka pengaruh orientasi kewirausahaan terhadap keunggulan bersaing adalah signifikan. Dengan demikian, maka hipotesis $4\left(\mathrm{H}_{4}\right)$ yang menyatakan bahwa orientasi kewirausahaan berpengaruh positif dan signifikan terhadap keunggulan bersaing diterima. 
INOBIS: Jurnal Inovasi Bisnis dan Manajemen Indonesia

Volume 1, Nomor 2, Maret 2018

Nyoman Gede Aditya Jay Medhika; I Gusti Ayu Ketut Giantri; Ni Nyoman Kerti Yasa

Pengujian hipotesis pada pengaruh keunggulan bersaing terhadap kinerja UKM menghasilkan nilai koefisien korelasi sebesar 0,323. Nilai $t$ Statistics didapat 2,121 (> t-kritis 1,96), maka pengaruh keunggulan bersaing terhadap kinerja UKM adalah signifikan. Dengan demikian, maka hipotesis $5\left(\mathrm{H}_{5}\right)$ yang menyatakan bahwa keunggulan bersaing berpengaruh positif dan signifikan terhadap kinerja UKM diterima.

Hasil pengujian mediasi dengan metode VAF telah memenuhi beberapa persyaratan yaitu, pertama, pengaruh langsung ditemukan signifikan (a) saat variabel keunggulan bersaing $\left(\mathrm{Y}_{1}\right)$ belum dimasukkan ke dalam model. Kedua, setelah variabel keunggulan bersaing $\left(\mathrm{Y}_{1}\right)$ dimasukkan ke dalam model, maka pengaruh tidak langsung (b x c) ditemukan pula signifikan. Jalur yaitu b dan c juga signifikan. Ketiga, menghitung Variance Accounted For (VAF) dengan rumus:

$$
\begin{aligned}
\mathrm{VAF} & =(0,871 \times 0,566) /(0,871+0,566 \times 0,883) \\
& =0,388 \text { atau } 38,8 \text { persen }
\end{aligned}
$$

Karena nilai VAF (38,8 persen) berada di rentang 20 persen hingga 80 persen, maka dapat dikategorikan sebagai pemediasi parsial (partial mediation). Dengan demikian, maka hipotesis 6 $\left(\mathrm{H}_{6}\right)$ yang menyatakan bahwa keunggulan bersaing memediasi pengaruh orientasi pasar terhadap kinerja UKM diterima.

Hasil pengujian mediasi dengan metode VAF telah memenuhi beberapa persyaratan yaitu, pertama, pengaruh langsung (e) variabel orientasi kewirausahaan $\left(\mathrm{X}_{2}\right)$ terhadap kinerja UKM $\left(\mathrm{Y}_{2}\right)$ tanpa melibatkan variabel mediasi keunggulan bersaing $\left(\mathrm{Y}_{1}\right)$ pada model, telah ditemukan signifikan. Kedua, setelah variabel keunggulan bersaing $\left(\mathrm{Y}_{1}\right)$ dimasukkan ke dalam model, maka pengaruh tidak langsung ( $\mathrm{f}$ x g) ditemukan signifikan. Jalur $\mathrm{f}$ dan $\mathrm{g}$ juga signifikan. Ketiga, menghitung Variance Accounted For (VAF) dengan rumus:

$$
\begin{aligned}
\mathrm{VAF} & =(0,872 \times 0,472) /(0,872+0,472 \times 0,907) \\
& =0,338 \text { atau } 33,8 \text { persen }
\end{aligned}
$$

Karena nilai VAF (33,8 persen) berada di rentang 20 persen hingga 80 persen, maka dapat dikategorikan sebagai pemediasi parsial (partial mediation). Dengan demikian, maka hipotesis 7 $\left(\mathrm{H}_{7}\right)$ yang menyatakan bahwa keunggulan bersaing memediasi pengaruh orientasi kewirausahaan terhadap kinerja UKM diterima.

Hasil pengujian menemukan pengaruh positif dari variabel orientasi pasar terhadap keunggulan bersaing yang artinya $\mathrm{H}_{1}$ diterima. Hasil penelitian sesuai dengan penelitian sebelumnya oleh Akhiri (2016) dan Usvita (2014) yang menemukan bahwa orientasi pasar berpengaruh positif dan signifikan terhadap keunggulan bersaing pada UKM. Penelitian tersebut mejelaskan bahwa perilaku orientasi pasar dalam bentuk orientasi yang tinggi pada pesaing, pencarian informasi pasar, dan orientasi pelanggan akan dapat meningkatkan kemampuan keunggulan bersaing UKM.

Berdasarkan hasil pengujian pada hipotesis, ditemukan pengaruh yang positif antara variabel orientasi kewirausahaan terhadap keunggulan bersaing yang artinya $\mathrm{H}_{2}$ diterima. Hasil penelitian ini sesuai dengan penelitian yang dilakukan oleh Usvita (2014), Akhiri (2016), Hajar dan Sukaatmadja (2016) juga menemukan hasil bahwa semakin tinggi tingkat orientasi 
INOBIS: Jurnal Inovasi Bisnis dan Manajemen Indonesia

Volume 1, Nomor 2, Maret 2018

Nyoman Gede Aditya Jay Medhika; I Gusti Ayu Ketut Giantri; Ni Nyoman Kerti Yasa

kewirausahaan pada sebuah UKM maka akan semakin tinggi pula keunggulan bersaing pada UKM tersebut.

Berdasarkan hasil pengujian pada hipotesis, ditemukan pengaruh positif signifikan antara variabel orientasi pasar terhadap kinerja UKM yang artinya semakin baik orientasi pasar yang dilakukan oleh UKM industri endek maka semakin tinggi kinerja UKM endek tersebut. Hasil penelitian ini sesuai dengan penelitian Pramesti \& Giantari (2016), dan Setiawan (2013) yang juga menemukan bahwa orientasi pasar berpengaruh positif dan signifikan terhadap kinerja pada UKM endek di Kabupaten Klungkung. Hasil penelitian ini memiliki arti bahwa meningkatnya budaya orientasi pasar pada UKM endek di Kabupaten Klungkung akan mampu meningkatkan kinerja UKM.

Berdasarkan hasil pengujian pada hipotesis, ditemukan pengaruh yang positif antara variabel orientasi kewirausahaan terhadap kinerja UKM yang artinya $\mathrm{H}_{4}$ diterima. Hasil ini menunjukkan bahwa semakin baik budaya orientasi kewirausahaan maka semakin tinggi kinerja UKM kain endek. Hasil penelitian ini sesuai dengan kajian yang dilakuakan oleh Pramesti \& Giantari (2016), Setiawan (2013) dan Hajar \& Sukaatmadja (2016) juga memperoleh hasil bahwa variabel orientasi kewirausahaan berpengaruh positif dan signifikan terhadap kinerja.

Berdasarkan hasil pengujian pada hipotesis, ditemukan pengaruh yang positif antara variabel orientasi pasar terhadap kinerja UKM melalui variable keunggulan bersaing yang artinya $\mathrm{H}_{5}$ diterima. Artinya keunggulan bersaing secara positif dan signifikan memediasi pengaruh orientasi pasar terhadap kinerja UKM industri kerajinan endek di Kabupaten Klungkung, memiliki makna bahwa orientasi pasar yang sudah dilakukan industri kerajinan kain endek di Kabupaten Klungkung mampu meningkatkan kinerja UKM secara langsung dan tidak langsung melalui keunggulan bersaing UKM tersebut. Penelitian ini juga sesuai dengan kajian yang dilakukan oleh Fatonah (2009) dan Usvita (2014) yang menyatakan bahwa keunggulan bersaing memediasi hubungan antara orientasi pasar dengan kinerja bisnis pada UKM.

Berdasarkan hasil pengujian pada hipotesis, ditemukan pengaruh yang positif antara variabel orientasi kewirausahaan terhadap kinerja UKM melalui variabel keunggulan bersaing yang artinya $\mathrm{H}_{6}$ diterima. Hasil penelitian ini sesuai dengan penelitian yang dilakukan oleh Alimudin (2014), Usvita (2014), Hajar dan Sukaatmadja (2016), serta Mahmood dan Hanafi (2013) yang memperoleh hasil bahwa keunggulan bersaing secara positif dan signifikan memediasi hubungan antara orientasi kewirausahaan dengan kinerja bisnis pada UKM. Temuan menggambarkan pentingnya sumber keunggulan bersaing sebagai penghubung dalam meningkatkan hubungan antara orientasi kewirausahaan dan kinerja UKM. Keunggulan bersaing tidak tergantung pada sumber daya alam, teknologi, atau skala ekonomi, tetapi pada sumber daya yang sulit ditiru yang berada dalam perusahaan.

Berdasarkan hasil pengujian pada hipotesis, ditemukan pengaruh yang positif antara variabel keunggulan bersaing terhadap kinerja UKM yang artinya $\mathrm{H}_{7}$ diterima. Hasil penelitian ini didukung oleh penelitian yang dilakukan oleh Hajar dan Sukaatmadja (2016) yang menemukan hasil bahwa keunggulan bersaing berpengaruh positif dan signifikan terhadap kinerja kinerja UKM. Perusahaan yang mampu menciptakan keunggulan bersaing akan memiliki kekuatan untuk bersaing dengan perusahaan lainnya karena produknya akan tetap diminati oleh pelanggan. 
INOBIS: Jurnal Inovasi Bisnis dan Manajemen Indonesia

Volume 1, Nomor 2, Maret 2018

Nyoman Gede Aditya Jay Medhika; I Gusti Ayu Ketut Giantri; Ni Nyoman Kerti Yasa

\section{Simpulan}

Berdasarkan hasil analisis penelitian dan hasil pembahasan yang telah dilakukan, maka dapat diambil beberapa simpulan dari penelitian ini yaitu 1) orientasi pasar berpengaruh positif dan signfikan terhadap keunggulan bersaing UKM industri kerajinan kain endek di Kabupaten Klungkung. Hal ini menunjukan bahwa semakin tinggi orientasi pasar, maka semakin tinggi keunggulan bersaing yang terbentuk pada UKM industri kerajinan kain endek di Kabupaten Klungkung. 2) Orientasi kewirausahaan berpengaruh positif dan signfikan terhadap keunggulan bersaing UKM industri kerajinan kain endek di Kabupaten Klungkung. Hal ini menunjukan bahwa semakin tinggi penerapan orientasi kewirausahaan oleh pelaku usaha maka semakin tinggi keunggulan bersaing yang terbentuk pada UKM industri kerajinan kain endek di Kabupaten Klungkung. 3) Orientasi pasar berpengaruh positif dan signfikan terhadap kinerja UKM industri kerajinan kain endek di Kabupaten Klungkung. Hal ini menunjukan bahwa semakin tinggi orientasi pasar, maka semakin tinggi kinerja yang terbentuk pada UKM industri kerajinan kain endek di Kabupaten Klungkung. 4) Orientasi kewirausahaan berpengaruh positif dan signfikan terhadap kinerja UKM industri kerajinan kain endek di Kabupaten Klungkung. Hal ini menunjukan bahwa semakin tinggi penerapan orientasi kewirausahaan oleh pelaku usaha maka semakin tinggi kinerja yang terbentuk pada UKM industri kerajinan kain endek di Kabupaten Klungkung. 5) Keunggulan bersaing secara positif dan signifikan memediasi pengaruh orientasi pasar terhadap kinerja UKM industri kerajinan endek di Kabupaten Klungkung. Hal ini menunjukan bahwa pelaku usaha kerajinan endek yang telah melakukan orientasi pasar akan mempunyai keunggulan bersaing dan hal tersebut akan mampu meningkatkan kinerja UKM industri kerajinan endek di Kabupaten Klungkung. 6) Keunggulan bersaing secara positif dan signifikan memediasi pengaruh orientasi kewirausahaan terhadap kinerja UKM industri kerajinan endek di Kabupaten Klungkung. Hal ini menunjukan bahwa pelaku usaha kerajinan endek yang telah melakukan orientasi kewirausahaan dengan baik dapat meningkatkan keunggulan bersaing sehingga dapat menciptakan dan membuat keputusan strategi-strategi yang sesuai dengan tujuan dan target usaha yang dapat meningkatkan kinerja UKM industri kerajinan endek di Kabupaten Klungkung. 7) Keunggulan Bersaing berpengaruh positif dan signifikan terhadap Kinerja UKM industri kerajinan endek di Kabupaten Klungkung. Hal ini menunjukkan bahwa semakin tinggi keunggulan bersaing yang ada pada UKM industri kerajinan endek di Kabupaten Klungkung, maka akan meningkatkan kinerja para pelaku usaha pada industri tersebut.

\section{Daftar Referensi}

Akhiri. 2016. Mencapai Keunggulan Bersaing Melalui Orientasi Pasar Dan Orientasi Kewirausahaan Dalam Rangka Meningkatkan Kinerja Bisnis Studi Pada UKM Pengolahan Tepung Tapioka Di Ngemplak Kidul Margoyoso Kabupaten Pati. Disertasi.

Alimudin, A. 2014. Pengaruh Orientasi Wirausaha Terhadap Keunggulan Bersaing Berkelanjutan Dan Kinerja Pemasaran Usaha Kecil Sektor Perdagangan (Consumer Goods) Di Kota Surabaya. Sustainable Competitive Advantage (SCA), 3(1): 1-9.

Assauri, Sofjan. 2013. Strategic Management: Sustainable Competitive Advantage. Jakarta: PT Raja Grafindo Persada 
INOBIS: Jurnal Inovasi Bisnis dan Manajemen Indonesia

Volume 1, Nomor 2, Maret 2018

Nyoman Gede Aditya Jay Medhika; I Gusti Ayu Ketut Giantri; Ni Nyoman Kerti Yasa

Dewi, N., dan Suparna, G. (2017). Peran Inovasi Dalam Memediasi Pengaruh Orientasi Kewirausahaan Terhadap Keunggulan Bersaing Industri Kain Endek. E-Jurnal Manajemen Universitas Udayana. 6(9): 5144 - 5174

Didonet, S., Simmons, G., Díaz-Villavicencio, G., dan Palmer, M. 2012. The relationship between small business market orientation and environmental uncertainty. Marketing Intelligence \& Planning. 30(7): 757-779.

Ekawati, N. W., Rahyuda, I. K., Yasa, K. N. N., dan Sukaatmadja, I. P. G. 2016. Implementation of Ecoprenership and Green Innovation in Building Competitive Advantage to Generate Success of New Spa Products in Bali. International Bussiness Management, 10 (14): 2660-2669.

Fatonah, S., 2009. Pengaruh Bauran Pemasaran, Dan Orientasi Pasar Terhadap Keunggulan Bersaing Dalam Meningkatkan Kinerja Pemasaran Pada Perusahaan Batik Di Surakarta. DIE. 6(1): 95-182.

Gradistya, G., O., dan Naili Frida. 2016. Pengaruh Orientasi Pasar Dan Orientasi Kewirausahaan Terhadap Kinerja Pemasaran Melalui Inovasi Sebagai Variabel Intervening (Studi Pada Umkm Batik Di Jawa Tengah). Jurnal Ilmu Administrasi Bisnis. Universitas Diponogoro. 3(5): 1-9.

Hadiyati, Ernani. 2011. Kreatifitas dan Inovasi Berpengaruh Terhadap Kewirausahaan Usaha Kecil. Jurnal Manajemen dan Kewirausahaan. 1(13): 8-16

Hajar, S. 2016 dan Sukaatmadja, I. P. G. Peran Keunggulan Bersaing Memediasi Pengaruh Orientasi Kewirausahaan Terhadap Kinerja Pemasaran. E-Jurnal Manajemen Unud. 5(10) : 6580-6609

Hartini, S. 2017. Hubungan Orientasi Pasar, Strategi Bersaing, Kewirausahaan Korporasi Dan Kinerja Perusahaan. Ekuitas (Jurnal Ekonomi dan Keuangan). 17(1): 39-53.

Hasan, Ali. 2014. Marketing dan Kasus-kasus Pilihan. Yogyakarta: CAPS.

Kotler, Philip. Gary Armstrong. 2012. Principle of Marketing Ed. 14th. United Kingdom: Pearson Education Limited.

Lumbanraja, P. 2011. Bersama UKM Membangun Ekonomi Rakyat dan Lingkungan Hidup. Jurnal Ekonom, 14(2): 87-93.

Lumpkin, G.T. dan G.G. Dess. 1996. Clarifying The Entrepreneurial Orientation Construct and Linking it to Performance. Academy of Management Review. 21(1): 135-172.

Mahmood, R. dan Hanafi, N. 2013. Entrepreneurial orientation and business performance of women-owned small and medium enterprises in malaysia: competitive advantage as a mediator. International Journal of Business and Social Science. 4(1): 82-90.

Porter, Michael, E, 1990, Competitive Strategy, The Free Press, New York.

Pramesti, N. M V., dan Giantari, I. G. A. K. 2016. Peran Orientasi Pasar Memediasi Pengaruh Orientasi Kewirausahaan Terhadap Kinerja UKM Industri Kerajinan Endek. E-Jurnal Manajemen Unud. 5(9): 5754-5782

Usvita, M. 2014. Pengaruh Orientasi Kewirausahaan dan Orientasi Pasar Terhadap Kinerja Perusahaan Melalui Keunggulan Bersaing Sebagai Variabel Intervening (Survei Pada UKM Pangan Dinas Perindagtamben Kota Padang). e-Jurnal Apresiasi Ekonomi, 3(1): 31-37.

Setiawan, H. 2013. Pengaruh Orientasi Pasar, Budaya Organisasi Dan Orientasi Kewirausahaan Terhadap Kinerja Usaha (Studi Pada Usaha Kecil Pengolahan Di Kota Palembang). Jurnal Manajemen Dan Bisnis Sriwijaya. 11(3): 181-194. 
INOBIS: Jurnal Inovasi Bisnis dan Manajemen Indonesia

Volume 1, Nomor 2, Maret 2018

Nyoman Gede Aditya Jay Medhika; I Gusti Ayu Ketut Giantri; Ni Nyoman Kerti Yasa

Shahbaz, Mian Awais., Asifah Javed., Aminar Dar., Tanzeela Sattar. 2014. Performance Measurement of Small Medium Enterprises (SMEs) in Pakistan. Archives of Business Research. 2(3): 42-49

Song, X. M., dan Perry, M. E. 1997. The Determinants of Japanese New Product Successes. Journal of Marketing Research. 34(1): 64-76

Zhang, David D., dan Edward Bruning. 2011. Personal Characteristics and Strategic Orientation: Entrepreneurs in Canadia Manufacturing Companies.International. Journal of Entrepreneurial Behavior and Research. 17(1): $82-103$. 